\title{
The Evaluation of Platelet Volume Indices in Patients with Varicocele
}

\section{Varikoseli Olan Hastalarda Trombosit Hacim İndekslerinin Değerlendirilmesi}

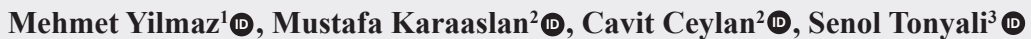

1 Department of Urology, Zile State Hospital, Tokat, Turkey

2 Department of Urology, University of Health Sciences, Ankara City Hospital, Ankara, Turkey

3 Department of Urology, Istanbul University Faculty of Medicine, Istanbul, Turkey

Cite as: Yilmaz M, Karaaslan M, Ceylan C, Tonyali S. The evaluation of platelet volume indices in patients with varicocele. Grand J Urol 2021;1(1):6-8.

Submission date: 04 December 2020

Acceptance date: 11 December 2020

Online first: 17 December 2020

Publication date: 20 January 2021

Corresponding Author: Mehmet Yilmaz / Zile State Hospital, Department of Urology, Tokat, Turkey yilmazmehmet88@hotmail.com ORCID: 0000-0003-3774-9982

\begin{abstract}
Objective: Varicocele is the abnormal venous dilatation and the tortuosity of the pampiniform plexus. Varicocele has been shown to be related with systemic varicosity in some studies. Platelet volume indices have also been reported to increase in vascular disorders. In this study, we aimed to determine if complete blood count (CBC) parameters especially platelet counts and volume indices could be a practical tool in the diagnosis and follow-up of varicocele.

Materials and Methods: The medical records of all patients who underwent varicocelectomy due to grade 2 or 3 clinical varicocele were reviewed. Examined parameters included patient demographic characteristics and preoperative CBC parameters [hemoglobin, white blood cell, platelet, mean platelet volume (MPV) and platelet distribution width (PDW)]. Patients without varicocele, active infection and vascular disorders constituted the control group.

Results: The study population consisted of 61 patients with varicocele and 62 control subjects. The mean age of the patients was $28.6 \pm 6.2$ years. Mean preoperative hemoglobin, WBC, platelet, MPV and PDW were $15.5 \pm 1 \mathrm{~g} / \mathrm{dL}, 7.5 \pm 1.6 \times 10^{3} / \mu \mathrm{L},(236 \pm 53.4) \times 10^{3} / \mu \mathrm{L}, 9.3 \pm 1.1(\mathrm{fL})$ and $15.2 \pm 3.9(\%)$, respectively. There was no difference between patients with varicocele and control subjects in terms of age, mean preoperative Hb, WBC and MPV. However, mean preoperative platelet count was significantly lower and mean PDW was significantly higher in varicocele patients compared to controls $(\mathrm{p}<0.05)$.

Conclusion: We found that PDW is significantly higher in varicocele patients compared to controls. Thus, PDW might be a practical tool in the confirmation of varicocele diagnosis and also be utilized at follow-up after varicocelectomy.
\end{abstract}

Keywords: varicocele, platelet, blood, $\mathrm{CBC}$

Öz

Amaç: Varikosel, anormal venöz genişleme ve pampiniform pleksusun tortiyoze olmasıdır. Bazı çalışmalarda varikoselin sistemik varikosite ile ilişkili olduğu gösterilmiştir. Trombosit hacim indekslerinin de vasküler bozukluklarda arttığı bildirilmiştir. Bu çalışmada, tam kan sayımı (CBC) parametrelerinin, özellikle trombosit sayısı ve hacim indekslerinin varikosel tanı ve takibinde kullanılıp kullanılamayacağını belirlemeyi amaçladık.

Yöntem ve Gereçler: Grade 2 veya 3 klinik varikosel nedeniyle varikoselektomi yapılan tüm hastaların tıbbi kayıtları gözden geçirildi. İncelenen parametreler hasta demografiklerini, ameliyat öncesi CBC parametrelerini [hemoglobin, beyaz kan hücresi, trombosit, ortalama trombosit hacmi (MPV) ve trombosit dağılım genişliğini (PDW)] içeriyordu. Kontrol grubu varikoseli, aktif enfeksiyonu ve damar rahatsızlığı olmayan hastalardan oluşturuldu. Bulgular: Çalışmaya 61'i varikoselli ve 62'si kontrol olmak üzere 123 hasta dahil edildi. Hastaların ortalama yaşı $28.6 \pm 6.2$ yıldı. Ortalama preoperatif hemoglobin, WBC, trombosit, MPV ve PDW sirası ile $15,5 \pm 1 \mathrm{~g} / \mathrm{dL}, 7,5 \pm 1,6 \times 10^{3} / \mu \mathrm{L},(236 \pm 53,4) \times 10^{3} / \mu \mathrm{L}, 9,3 \pm 1,1(\mathrm{fL})$ ve $15,2 \pm 3,9(\%)$ idi. Yaş, ameliyat öncesi $\mathrm{Hb}$, Wbc ve MPV açısından varikoseli olan hastalarla kontroller arasında fark yoktu. Bununla birlikte, kontrollere göre varikosel hastalarında ameliyat öncesi ortalama trombosit sayısı anlamlı olarak düşüktü ve ortalama PDW anlamlı olarak yüksekti ( $\mathrm{p}<0.05)$.

Sonuç: Varikosel hastalarında PDW'nin kontrollere göre anlamlı olarak daha yüksek olduğunu bulduk. Bu nedenle PDW, varikosel tanısının doğrulanmasında pratik bir araç olabilir ve aynı zamanda varikoselektomi sonrası takipte de kullanılabilir.

Anahtar Kelimeler: varikosel, platelet, kan 


\section{Introduction}

Varicocele is a disease characterized by abnormal enlargements in the testicular vein and pampiniform plexus caused by various factors [1]. Varicocele is found in about $15 \%$ of men and represents the primary cause of male infertility in $35 \%$ of cases [2]. The etiology of varicocele is multifactorial and the pathogenic mechanisms of varicocele are unclear, but varicocele may lead to increased venous pressure, high testicular temperature, oxidative stress, hypoxia and ultimately testicular damage [3]. According to previous studies, it is known that oxidative stress enhances vascular inflammation, which plays an important role in the progression of atherosclerotic disease [4]. Varicocele is a vascular disease and causes local and / or systemic inflammation [5]. In addition, a systemic vascular varicosity was positively correlated with varicocele [6]. Changes in platelet function caused by vascular damage can be associated with varicocele [2].

In this study, we aimed to determine if complete blood count (CBC) parameters especially platelet count and volume indices could be a practical tool in the diagnosis and follow-up of varicocele.

\section{Materials and Methods}

After obtaining institutional review board approval (Approval Number: 2018/29620911-929), the medical records of all patients who underwent varicocelectomy due to grade 2 or 3 clinical varicocele in Türkiye Yüksek İhtisas Training and Research Hospital between 2014 and 2018 were retrospectively reviewed. Patients who underwent unilateral varicocelectomy without any active infection constituted the patient group. Patients admitted to outpatient clinic with a complaint other than infertility or scrotal pain without varicocele, active infection, inflammatory disease and vascular disorders constituted the control group.

\section{Statistical Analysis}

IBM SPSS statistical package programme v.21 for Mac (Armonk, NY, USA)was used. Quantitative variables were given as mean \pm standard deviation and qualitative values were shown in numbers and percentages. Comparison of variables between two groups was made by using Mann-Whitney U tests. Statistical significance was set as $\mathrm{P}<0.05$

\section{Results}

The study included 61 patients with varicocele and 62 control subjects. The mean age of the patients was $28.6 \pm 6.2$ years. Mean preoperative hemoglobin, WBC, platelet, MPV and PDW values were $15.5 \pm 1 \mathrm{~g} / \mathrm{dL}, 7.5 \pm 1.610^{3} / \mu \mathrm{L}, 236 \pm 53.4$ $\mathrm{x} 10^{3} / \mu \mathrm{L}, 9.3 \pm 1.1(\mathrm{fL})$ and $15.2 \pm 3.9(\%)$, respectively. There was no difference between patients with varicocele and controls in terms of age ( $28 \pm 6.8$ vs $29.1 \pm 5.5$ years), mean preoperative $\mathrm{Hb}(15.6 \pm 0.9$ vs. $15.4 \pm 1.1 \mathrm{~g} / \mathrm{dL}), \mathrm{WBC}(7.4 \pm 1.6$ vs $7.6 \pm 1.6$ $\left.\mathrm{x} 10^{3} / \mu \mathrm{L}\right)$ and $\mathrm{MPV}(9.3 \pm 1.1$ vs $9.4 \pm 1 \mathrm{fL})$. However, mean preoperative platelet count was significantly lower and mean PDW was significantly higher in varicocele patients compared to controls ( $\mathrm{p}=0.006$ and $\mathrm{p}=0.001$, respectively) (Table $\mathbf{1}$ ).

\section{Discussion}

Underlying pathogenesis of varicocelecan be related to increased pressure in the pampiniform venous plexus and venous drainage [7]. Many studies have been conducted in the literature to elucidate the exact etiology of varicocele. In the literature, it is reported that the presence of large platelets is a possible risk factor for the diseases and the conditions such as testicular torsion, varicocele, stroke, myocardial infarction and angina, coronary artery atherosclerosis, malignancy, ulcerative colitis, familial Mediterranean fever, Alzheimer's disease and Behçet's disease [5]. Most of the mediators necessary for coagulation, inflammation, thrombosis and atherosclerosis are secreted by platelets [8].

Table 1. Comparison of age and complete blood count variables of varicocele patients and the control group

\begin{tabular}{l|l|l|l}
\hline Variables & $\begin{array}{l}\text { Varicocele } \\
(\mathbf{n}=61)\end{array}$ & $\begin{array}{l}\text { Control } \\
(\mathbf{n}=\mathbf{6 2})\end{array}$ & P value \\
\hline Age (yr) & $28 \pm 6.8$ & $29.1 \pm 5.5$ & 0.096 \\
\hline $\begin{array}{l}\text { Mean Preoperative } \\
\text { Hb (g/dL) }\end{array}$ & $15.6 \pm 0.9$ & $15.4 \pm 1.1$ & 0.455 \\
\hline $\begin{array}{l}\text { Mean Preoperative } \\
\text { WBC x 10 } / \mu \mathrm{L}\end{array}$ & $7.4 \pm 1.6$ & $7.6 \pm 1.6$ & 0.482 \\
\hline $\begin{array}{l}\text { Mean Preoperative } \\
\text { PLT x10 } / \mu L\end{array}$ & $222 \pm 47$ & $249 \pm 56$ & $\mathbf{0 . 0 0 6}$ \\
\hline $\begin{array}{l}\text { Mean Preoperative } \\
\text { MPV (fL) }\end{array}$ & $9.3 \pm 1.1$ & $9.4 \pm 1$ & 0.419 \\
\hline $\begin{array}{l}\text { Mean Preoperative } \\
\text { PDW (\%) }\end{array}$ & $16.2 \pm 4.5$ & $14.2 \pm 2.8$ & $\mathbf{0 . 0 0 1}$ \\
\hline
\end{tabular}

Hb: hemoglobin; WBC: white blood cell; PLT: platelet; MPV: mean platelet volume; PDW: platelet distribution width

Vascular change and platelet indices may be useful for detecting or screening subclinical varicocele [2]. Platelet indices such as mean platelet volume (MPV), platelet distribution width (PDW) and thrombocytecrit (PCT) are standard indicators of platelet function in the pathophysiology of diseases [9]. MPV is an important marker of platelet size and activation. However, the results of the studies on this subject in the literature are contradictory. In a study by Cüce et al., MPV values were found to be significantly higher in patients with varicocele than those without $(\mathrm{P}=0.010)$, but no statistically significant relationship was found between grade of varicocele and MPV and RDW values [4]. Bozkurt et al. stated that the increase in MPV was due to the varicocele disease and that the increase in the degree of varicocele was associated with higher MPV in varicocele patients [8]. In concordance with the aforementioned studies Coban et al. found that MPV values were significantly higher in the varicocele group, and platelet and PDW values were significantly lower than in the control group [1]. In another study, in contrast with our study, when the platelet (PLT), MPV, PCT and PDW values of the varicocele and the non-varicocele groups were compared, a significant increase was observed in MPV $(p=0.003)$, but no 
difference was observed in the platelet count or platelet indices [3].

In another study by Polat et al.,platelet counts or indices represented no difference between the groups with and without varicocele in terms of MPV, PDW and PCT [9]. Mahdavi et al. found that platelet volume indices [PVI (MPV, PDW, and $\mathrm{P}-\mathrm{LCR}$ )] was higher in varicocele patients compared to normal healthy controls [10]. In our study, no significant difference was observed between the groups with and without varicocele in terms of MPV, while the mean preoperative PDW value was found to be significantly higher in those with varicocele.

Our study is also not without limitations. One of the main limitations of the study is that the study is its retrospective design. In addition, the small number of patients and the fact that we did not measure other platelet indices like (platelet-large cell ratio (PLCR) and platelet-large cell concentration (PLCC) and platelet activation markers such as beta-thromboglobulin and platelet factor IV might be considered among the other limitations of our study.

\section{Conclusion}

We found that PDW is significantly higher in varicocele patients compared to controls. Thus, PDW might be a practical tool in the diagnostic confirmation of varicocele and also be utilized at follow-up after varicocelectomy.

Ethics Committee Approval: The study was approved by Higher Specialization Training and Research Hospital Medical Specialty Education Board (TUEK), Cankaya, Ankara, Turkey (Decision No: 15 March, 2018/29620911-929).

Informed Consent: An informed consent was obtained from all the patients.

Publication: The results of the study were not published elsewhere in full or in part in form of abstracts.

Peer-review: Externally peer-reviewed.

Authorship Contributions: Any contribution was not made by any individual not listed as an author. Concept - M.Y., M.K., C.C., S.T.; Design - M.Y., M.K., C.C., S.T.; Supervision M.Y., M.K., C.C., S.T.; Resources - M.Y., M.K., C.C., S.T.; Materials - M.Y., M.K., C.C., S.T.; Data Collection and/ or Processing - M.Y., M.K., C.C., S.T.; Analysis and/or Interpretation - M.Y., M.K., C.C., S.T.; Literature Search M.Y., M.K., C.C., S.T.; Writing-M.Y., M.K., C.C., S.T.; Critical Review - M.Y., M.K., C.C., S.T.

Conflict of Interest: The authors declare that theyhave no conflict of interest.

Financial Disclosure: The authors have declared that they did not receive any financial support for the realization of this study.

\section{References}

[1] Çoban S, Keleş I, Biyik I, Güzelsoy M, Türkoğlu AR, Özgünay $\mathrm{T}$, et al. Is there any relationship between mean platelet volume and varicocele? Andrologia 2015;47:37-41. https://doi.org/10.1111/and.12220.

[2] Pyo JS, Cho WJ. Mean Platelet Volume, Platelet Distribution Width, and Platelet Count in Varicocele: A Systematic Review and Meta-Analysis. Cell Physiol Biochem 2016;38:2239-46. https://doi.org/10.1159/000445579.

[3] Zhang QF, Liang JH, He TH, Huang ZX, Liu QL, Zhang $X$, et al. Relationship between varicocele and platelet indices: changes of mean platelet volume before and after operation. Andrology 2019;7:846-51. https://doi.org/10.1111/andr.12605.

[4] Cüce F, Demiray Ö, Küçük U, Olgun Küçük H. Varicocele: Tissue stress in the etiology. Turkish J Med Sci 2016;46:1014-7. https://doi.org/10.3906/sag-1411-70.

[5] Demirer Z, Karademir I, Uslu AU, Güragac A, Aksu Y. The relationship between inflammation and mean platelet volume in varicocele pathophysiology. Rev Int Androl 2018;16:137-42. https://doi.org/10.1016/j.androl.2017.06.005.

[6] Kiliç S, Aksoy Y, Sincer I, Oğuz F, Erdil N, Yetkin E. Cardiovascular evaluation of young patients with varicocele. Fertil Steril 2007;88:369-73. https://doi.org/10.1016/j.fertnstert.2006.11.119.

[7] Aslan R, Erbin A, Celik S, Ucpinar B, Sahinalp S, Y1ldızhan M, et al. Evaluation of hemorrhoidal disease and lower extremity venous insufficiency in primary adult varicocele: A prospective controlled study. Phlebology 2019;34:621-6. https://doi.org/10.1177/0268355519834426.

[8] Bozkurt Y, Soylemez H, Sancaktutar AA, Islamoglu Y, Kar A, Penbegul N, et al. Relationship between mean platelet volume and varicocele: A preliminary study. Urology 2012;79:1048-51. https://doi.org/10.1016/j.urology.2012.01.019.

[9] Polat H, Gulpinar MT, Sarıca MA, Benlioglu C. Relationship between mean platelet volume, platelet distribution width, plateletcrit and varicocele. Andrologia 2017;49. https://doi.org/10.1111/and.12594.

[10] Mahdavi-Zafarghandi R, Shakiba B, Keramati MR, Tavakkoli M. Platelet volume indices in patients with varicocele. Clin Exp Reprod Med 2014;41:92-5. https://doi.org/10.5653/cerm.2014.41.2.92. 